\author{
DANIJELA D. ĐORĐEVIĆ ${ }^{1}$ \\ UNIVERSITY OF BELGRADE \\ FACULTY OF AGRICULTURE \\ DEPARTMENT OF FOREIGN LANGUAGES \\ ANNA APOLONIA SteFANOWICZ-KOCOŁ ${ }^{2}$ \\ STATE HigheR VOCATIONAL SCHOOL OF TARNOW \\ FACULTY OF HUMANITIES \\ DEPARTMENT OF ENGLISH PHILOLOGY
}

\title{
STUDENTS' PERCEPTION OF INCORPORATING MOODLE IN AN ESP CONTEXT ${ }^{3}$
}

\begin{abstract}
A Moodle platform can be successfully integrated into any course for the purpose of introducing e-learning as well as blended learning. The aim of this paper was to investigate whether students were content with having the Moodle platform as a part of the course English for Specific Purposes. The respondents were the students of the Faculty of Agriculture, University of Belgrade. The primary objective of this research was to see whether students find e-learning, and the Moodle course in particular, favourable to their learning. Furthermore, we were also eager to hear about their attitudes towards communication with other students and the teacher as well as about their preferable form and way of learning. Finally, we wanted to learn how their self-assessment correlated with their attitudes towards e-learning in order to reach some conclusions for further research.
\end{abstract}

KEY WORDS: Moodle, e-learning, English for Specific Purposes, students' perception.

\footnotetext{
ddj@agrif.bg.ac.rs

anna.kocol@gmail.com

3 Рад је примљен 27. октобра 2016, а прихваћен за објављивање на састанку Редакције 3борника одржаном 9. децембра 2016.
} 
INTRODUCTION

A lot has been said about the potential of Computer Assisted Language Learning, with a wealth of research predicting its immense importance in the future, foreseeing ICT (Information and Communication Technologies) as a new form of literacy without which language learning may even be impossible (Warschauer, 2000). For the time being, while it is undeniable that the Web offers unlimited resources, they might be seen as not particularly appealing since they are drowned in a plethora of sites, with little or no quality assurance and guidance needed by language learners, especially on elementary and pre-intermediate levels. Also, although almost all students use mobiles and computers with Internet access, not all of them are enthusiastic about using technology in or out of the classroom for educational purposes. Using some technologies may seem an easy thing to do, but actually working with them on one's own on daily basis can be quite demanding and time-consuming.

An answer to the above mentioned problems may lie in blended learning. In a hybrid environment students are able to make use of all the advantages offered by the ICT technologies while being supported by regular face-to-face meetings with the teacher, which seems to be preferred by more and more students (Dudeney and Hockly, 2013). Debora Marsh (2012, p. 5) notices that in this way students acquire language in a more individualised way thanks to the possibility of personalising the online component to suit the various learning styles or language levels present in every classroom. She also points out that blended learning ensures safe environment where students are often involved in authentic tasks on the web. As a result the time spent practicing the target language, while flexible, is frequently expanded far beyond the classroom/homework time and tends to result in a more creative language use.

\section{MOODLE FOR LANGUAGE TEACHING}

Learning management system named Moodle (Modular Object-Oriented Dynamic Learning Environment) has the potential to fulfil the promises made by blended learning. Martin Dougiamas, initially constructed it to support self-directed learning: to give the learners control over content and pace of their learning activity (Dougiamas, 1998). Later on it was adapted to more formal forms of instruction, with the possibility of creating groups/classrooms, keeping track of 
scores (gradebook), and the opportunity to analyse the students' activity on the platform (statistical module).

Moodle is free open source software based on a theory called constructivism, which assumes that learners are active participants who create their own systems of knowledge using available sources of information. A more recent development of social constructivism indicates that the construction of knowledge is most effective if it is carried out in a cooperative way, sharing opinions, experiences and responding to the needs of other participants of the group (Siek-Piskozub, 2006). Teaching approaches based on social constructivist theory can include reciprocal teaching, peer collaboration, problem-based instruction, webquests, and other methods that involve pair work or group learning (Shunk, 2000).

The teacher who begins to use Moodle must bear in mind it is a tool not a resource. It provides the functionalities but lacks content (Elias, 2010). By some it is seen as a drawback, however, in an ESP classroom, where the teacher needs to ensure appropriate content for a given group of students with unique communication needs, Moodle gives the course creator the freedom to combine hand-picked resources, communication tools and interactive activities useful for language input, practice and production. The idea of customization is especially appealing to teachers of ESP, as the needs of these groups are not easily satisfied by using a unified textbook (Stefanowicz-Kocoł, 2015).

While designing such a course it is important to bear in mind the Universal Instructional Design Principles for Moodle set out by Elias (2010, p. 122). He recommends designing flexible environments accessible for people with diverse abilities and in diverse locations. What is also important is that the course should be kept clear, simple and intuitive so that the interface is easy to follow, regardless of the students' experience in using IT, prior knowledge, language skills or current concentration level. Another important factor to bear in mind, while creating a Moodle course, is the tolerance for error. It refers both to the technical side of the course creation and to the language in answers provided by students while doing quizzes or submitting assignments. While it may seem beneficial from the point of view of learner autonomy to give the students co-authoring rights to enable them to edit some course components it may bring about confusion if exercised in excess. When it comes to language that the electronic course components accept, it must be remembered that the platform will accept only the answer which is exactly 
the same as the one provided while creating the quiz. Therefore teachers must take care to create quiz items which do not demotivate students. Since students enjoy communicating with one another online each course should also include the possibility for students to engage in asynchronous interaction (Elias, 2010, p. 122).

A possible design of such a course might be organized by level, weekly or in a topic format, with a number of possible components such as forums, chats, glossaries, wikis, assignments, quizzes, choices (polls), games, databases, Sloodle, WiZiQ, MoodLL, etc. Such an environment must allow the users to store and organize resources (text, audio, video, web links and interactive activities) and communicate with one another and the teacher. It also gives the teachers the possibility to guide the learners, recommend content and set tasks that complement the material realised during face-to-face classes.

POSSIBLE CONCERNS

The question that arises here is whether learners are capable of participating in a course that requires a high level of self-control and initiative. Taking into consideration the growing popularity of the learning management system, its intuitiveness and flexibility, it seems highly probable from the technical point of view. It is also technically possible to give other participants the rights to be co-creators of content. It could empower and motivate them to get more engaged in the subject. It has been shown in a number of studies (Deller, 1990; Campbell \& Kryszewska, 1992; Stefanowicz-Kocoł \& Nowak, 2009; Stefanowicz-Kocol, 2011) that learners are able to successfully create content that is used by other learners for further practice and assessment, to the benefit of all interested parties.

Another concern is the students' readiness for such autonomous learning. Having in mind the students' educational background (secondary school), it is unlikely that they are prepared for independent learning. On the other hand, it is never too late to start developing this important capacity and it has been claimed that online learning can be utilised as a tool for the development of learner autonomy (Little, 1996; Warschauer, 2000; Shetzer \& Warschauer, 2000). 
MATERIAL AND METHODS

In the study outlined below we aimed at finding out what we could learn from ESP students' experience of participating in a blended ESP course. The general objective of our research was to see whether students were satisfied with using the Moodle in an ESP context, and to learn about their perception of advantages and disadvantages of using Moodle. Additionally, we were keen to find out about their attitudes towards communication with other students and the teacher within the Moodle environment as well as about their preferable form and way of learning. In the end, we also sought to see whether there were any correlations between their attitudes towards using computers/technology in the classroom and their grades, then between their self-evaluation and the grades, next between their grades and frequency of visiting Moodle, which can be a good starting point for some research in the future.

The respondents were the first-year students of the Faculty of Agriculture, University of Belgrade, Serbia attending the course English for Specific Purposes during the 2013/2014 academic year for one semester, that is, two lessons per week, 30 lessons in total.

These students had the opportunity on a voluntary basis to combine face-to-face learning with e-learning, that is, to experience blended learning. They were given materials on the Faculty of Agriculture Moodle site, namely, the lessons taught previously in the classroom were available online, provided with links to definitions of all unknown words as well as with questions checking their understanding of the text, i.e., the uploaded material. Additionally, different kinds of assignments and quizzes were available so that the students could practice and prepare for the examination. Unfortunately, not all students were eager to participate although they were informed that they would be awarded some extra points for participation. The reasons they usually stated for not participating were not having proper access to the Internet as well as not having a computer. Some of them admitted that they were lazy and not interested in Moodle while some of them simply claimed that they did not like such kind of studying.

The total number of students who responded voluntarily to the questionnaire administered at the end of the semester, after taking the examination was $104(\mathrm{n}=104), 64$ females and 40 males. They were informed in advance that their responses would be used for scientific purposes. 
The questions administered attempted to cover self-evaluation of their knowledge of English and computers before their enrolment at the Faculty, their (dis)satifaction with the material used on the Moodle platform, their view on possible improvement of their language and computer skills, communication with other students and the teacher, as well as advantages and disadvantages of blended learning.

\section{RESULTS AND DISCUSSION}

Regarding their knowledge of English before entering the Faculty, the respondents were asked to assess it on the scale from 1 (insufficient) to 5 (excellent) (Figure 1). About $41 \%$ of respondents evaluated their knowledge with a grade of 4 , a considerable number of respondents (32\%) chose 5 , and around $21 \%$ selected the grade of 3 , whereas only $5 \%$ of respondents opted for 2 , and only one respondent decided on the grade of 1 . Therefore, the majority of the respondents think that they have a relatively high level of English knowledge.

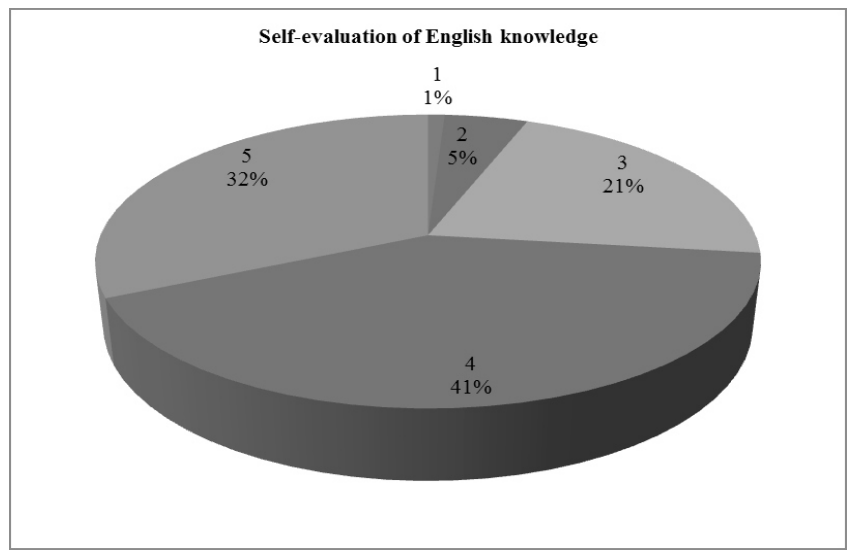

FIGURE 1. SELF-EVALUATION OF RESPONDENTS' KNOWLEDGE OF ENGLISH

As for the self-evaluation of their knowledge on using computers, the situation is a little different (Figure 2). Approximately $54 \%$ of the respondents thought that their knowledge was excellent with a grade of five. About $29 \%$ of respondents evaluated their computer knowledge with a grade of 4 , while $14 \%$ thought their grade should be 3 , and only $3 \%$ opted for the grade of 2 , and nobody of the re- 
spondents thought that they had no knowledge of computers, i.e. that they deserved a grade of 1 . Hence, compared with the previous question and answers, students felt even more confident when the computer skills were taken into account.

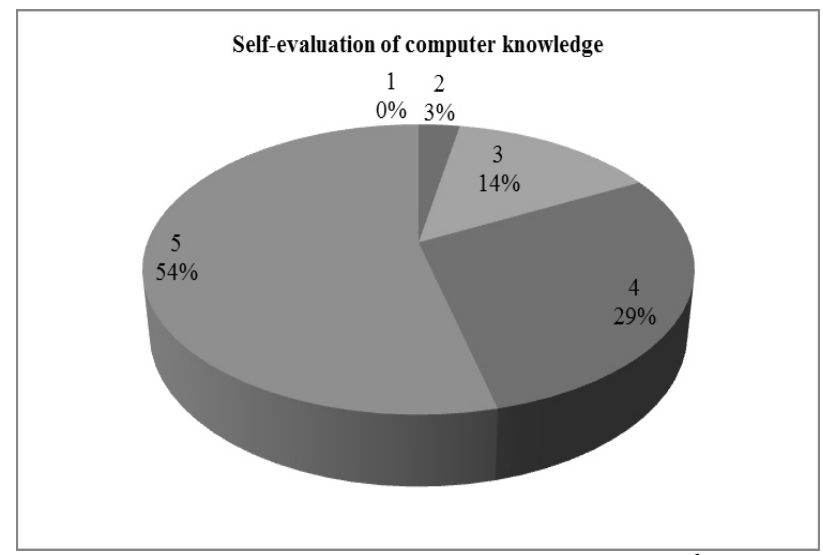

FIGURE 2. SELF-EVALUATION OF RESPONDENTS KNOWLEDGE OF COMPUTERS

When it comes to the advantages of using a Moodle platform in an ESP context (Figure 3), most respondents favoured the possibility to study when it suits them $(78 \%, \mathrm{n}=82)$, then the possibility to choose the place for studying $(36 \%, n=37)$, the possibility to choose the learning material $(27 \%, \mathrm{n}=28)$ and the possibility to avoid meeting a teacher and colleagues $(4 \%, n=4)$. About $4 \%(n=4)$ of the respondents opted for 'Other', stating that they did not like studying by means of a computer. On the other hand, some of them stated that they liked it because information was available in one place. Hence, the possibilities to study when and where they like seem as the most relevant of the mentioned advantages.

Regarding the disadvantages of using a Moodle platform, the majority of respondents elected the impossibility to have a direct contact with a teacher (65\%) and the lack of self-discipline to study when it is necessary (40\%), whereas about $9 \%$ of respondents chose difficult access to material, while about $8 \%$ opted for 'Other', stating reasons such as problems with eyesight, then the teacher not being able to know for sure who actually completed the task, the need for Internet access, whereas some of them claimed there were no disadvantages. We can see that for most respondents, having a direct contact with a teacher is very important. Similarly, the lack of 


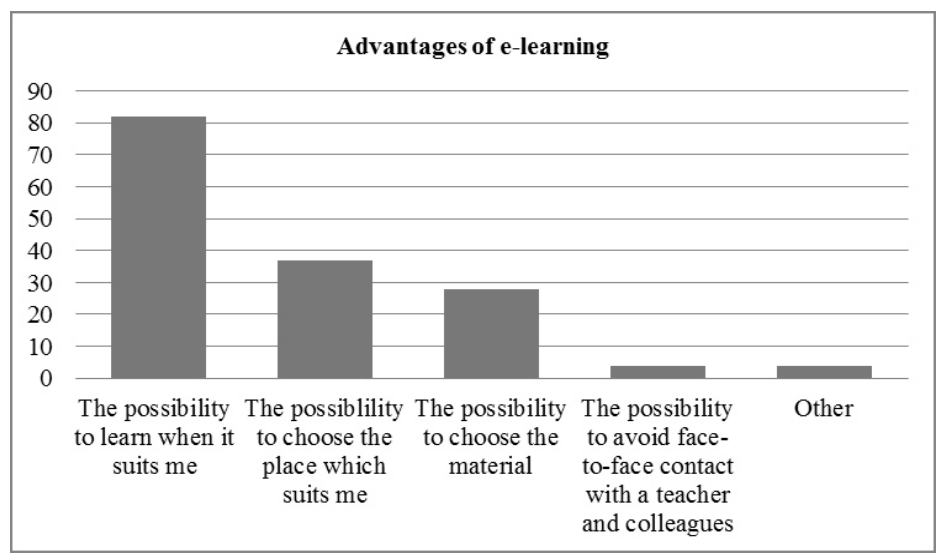

FIGURE 3. ADVANTAGES OF E-LEARNING

self-discipline can point to the fact that students are not autonomous enough.

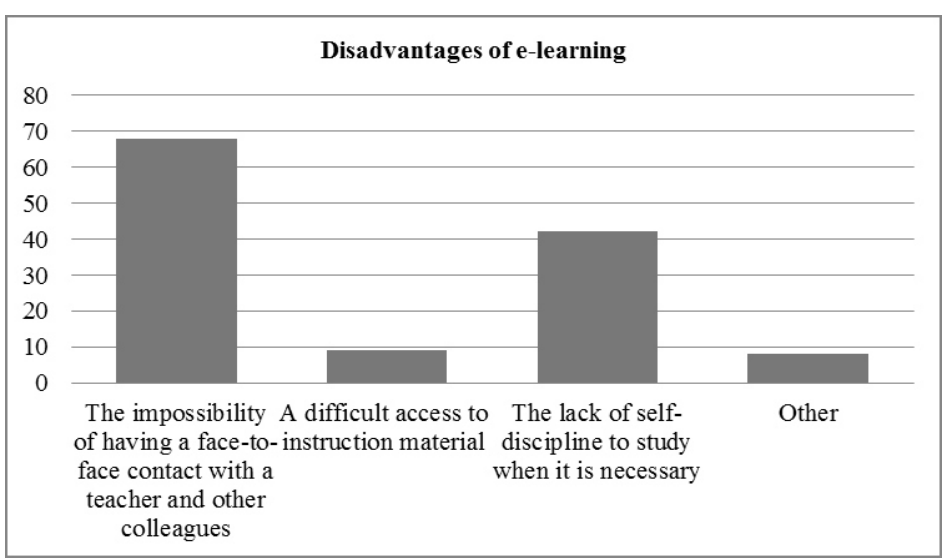

FIGURE 4. DiSADVANTAGES OF E-LEARNING

Taking into account the teaching material posted on the Moodle platform (Figure 5), respondents were asked to evaluate it. More than a half (64\%) marked it as excellent. About one-fourth of respondents thought that it was very good ( $25 \%)$, while $10 \%$ evaluated the material with a grade of 3 . Then, only $1 \%$ of respondents assessed the material with a grade of 2 . Fortunately, nobody opted for the grade of 1 and it is possible to say that students were generally satisfied with the material they were provided with. 


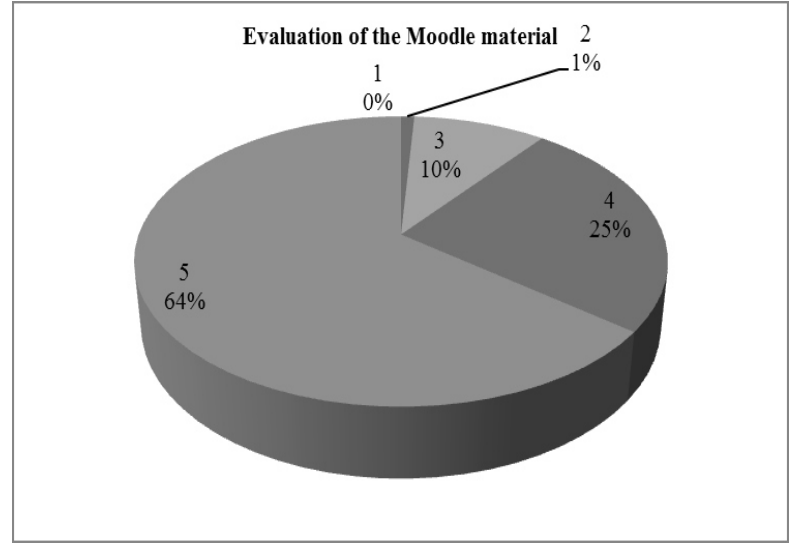

FIGURE 5. EVALUATION OF THE MATERIAL POSTED ON THE MOODLE PLATFORM

Concerning their opinion on the possible improvement of their knowledge of English (Figure 6), almost half of the respondents (47\%) believed that their knowledge improved, about $27 \%$ thought that it fairly improved, whereas around $22 \%$ considered that their knowledge did not quite improve, and roughly $4 \%$ believed that their knowledge did not improve at all. It is important to notice that more than a half of respondents were able to follow their own progress to some degree and to become conscious of their advancement. This can positively affect their learning as well as their motivation for learning, because in case of many students the importance of the awareness of being able to do something successfully was quite relevant.

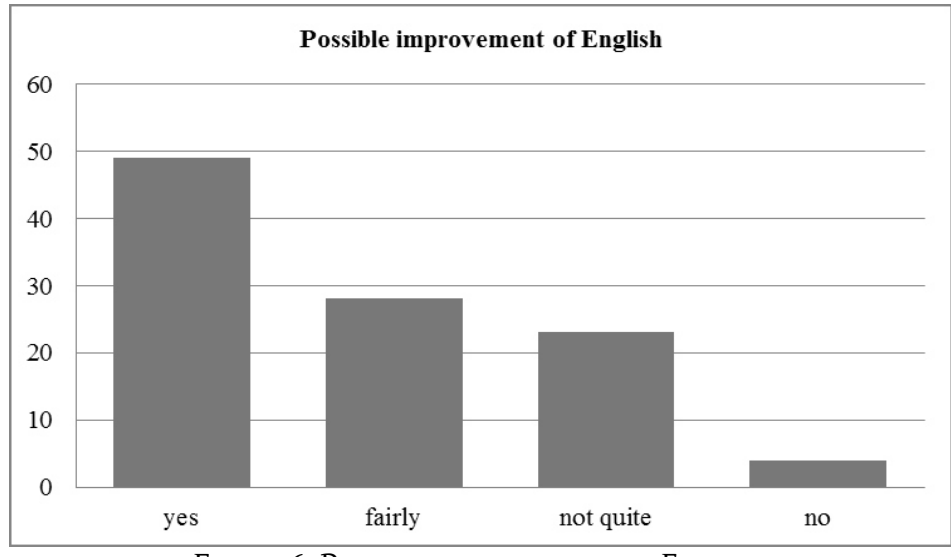

FIGURE 6. POSSIBLE IMPROVEMENT OF ENGLISH 
When it comes to the type of studying (Figure 7), most of students (83\%) preferred the combination of the two given options: classroom and through computers, whereas about $15 \%$ preferred classical face to face teaching, and only $2 \%$ opted for e-learning. We were satisfied with these results since it points to respondents' awareness of blended learning significance. In addition, their not opting for e-learning only may suggest that they are not quite willing and prepared for entirely independent learning since many of them consider e-learning as relying exclusively on their own without the additional help of the teacher.

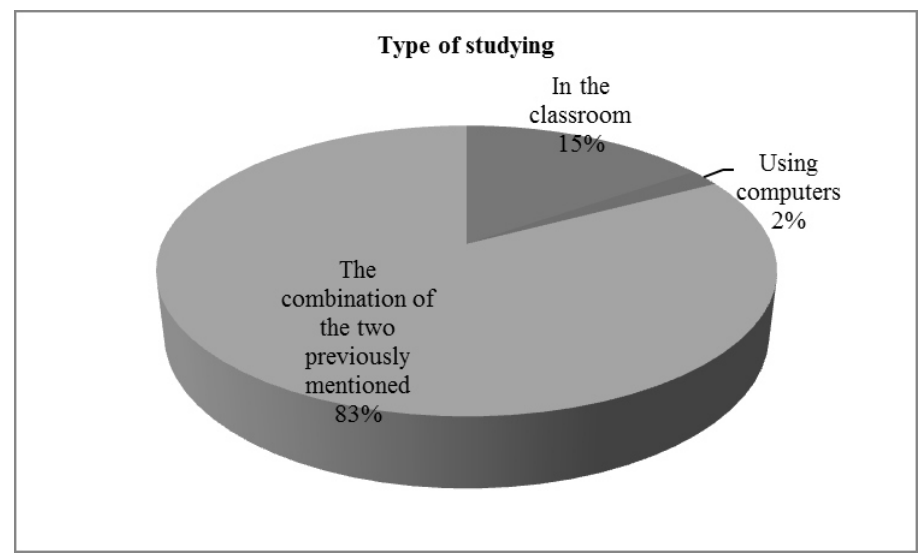

FIGURE 7. TYPE OF STUDYING

As for how they like to study (Figure 8), approximately 61\% like to listen to their teacher's lecture directly (face-to-face communication), about $53 \%$ like to highlight what they consider important, around $49 \%$ of respondents like to think before they provide an answer and the same percent think that they learn best when they see the information, and about $48 \%$ would like the teacher to correct them when they are wrong. What they like least is to read the material by themselves, study tables and figures, without teacher's presence (around 14\%), and only about $12 \%$ like to prepare for the next lesson and to revise the material taught during the previous lecture. It has already been mentioned that students like having a direct contact with their teacher, and that learning on their own may pose a problem for them. It may indicate that they are not accustomed to being independent, and hopefully introducing blended learning can help them overcome it. 


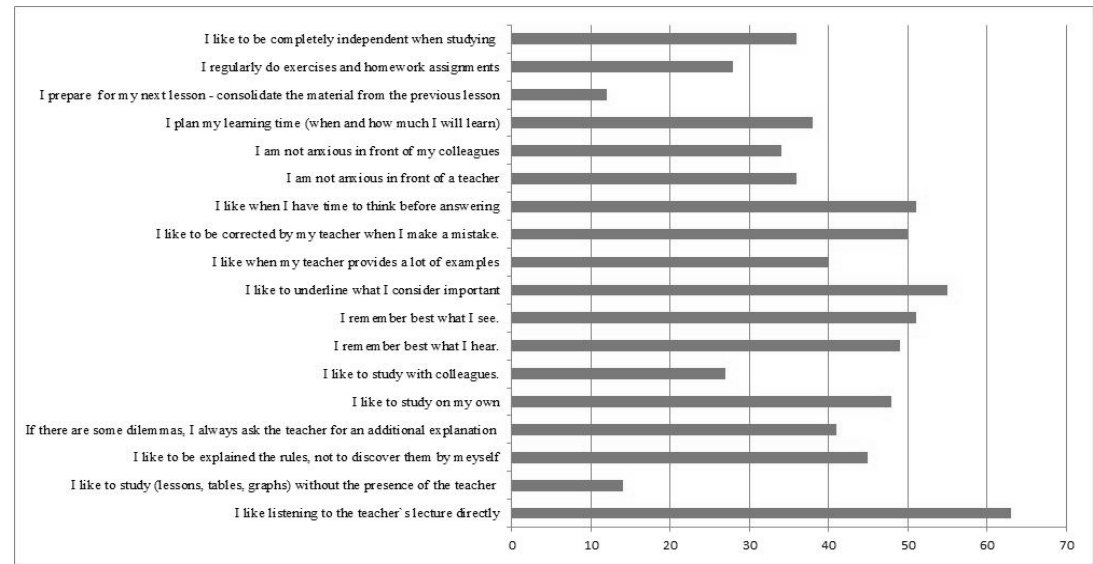

FIGURE 8. WAY OF STUDYING

When it comes to communication with a teacher and colleagues through the Internet, approximately $53 \%$ of respondents sometimes communicate, about $32 \%$ always communicate and only around $1 \%$ of the respondents never communicate with a teacher and colleagues by means of the Internet. It can be observed that about one third of the respondents seem to like this kind of communication, whereas, in practice, there is an impression that students are sometimes too shy or anxious when they ought to communicate through the Internet, by email, chat or forums.

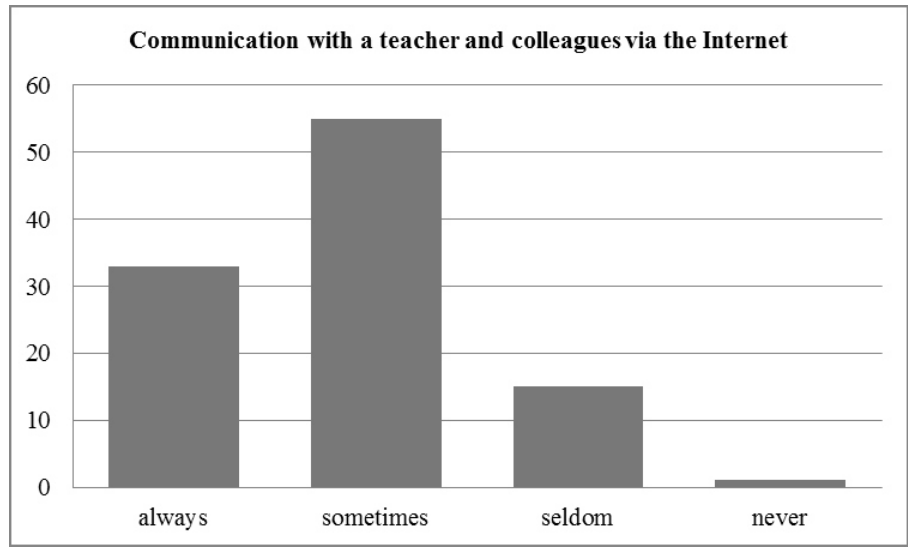

FIGURE 9. COMMUNICATION WITH A TEACHER AND COLLEAGUES VIA THE INTERNET

Considering the willingness of the respondents to contact their teacher when something is not clear to them, about $48 \%$ of respond- 
ents answered that they did it sometimes, while $28 \%$ did it rarely, and about $15 \%$ always did it. As we can see, respondents are not so eager to ask a teacher for help, possibly thinking that it may ruin their image or make them seem ignorant.

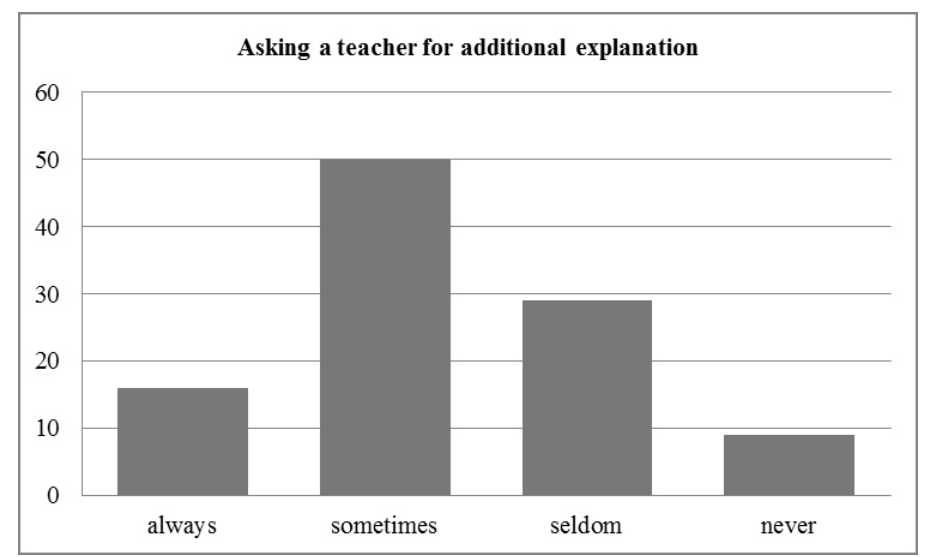

FIGURE 10. ASKING A TEACHER FOR ADDITIONAL EXPLANATION

Regarding respondents' willingness to ask their colleagues for help or some additional explanation, approximately $47 \%$ did it sometimes, whereas $41 \%$ did it always. This leads to the possible conclusion that the respondents were more eager to ask their colleagues for help rather than their teacher. Hence, it seems that respondents see cooperation as an important factor in the process of learning.

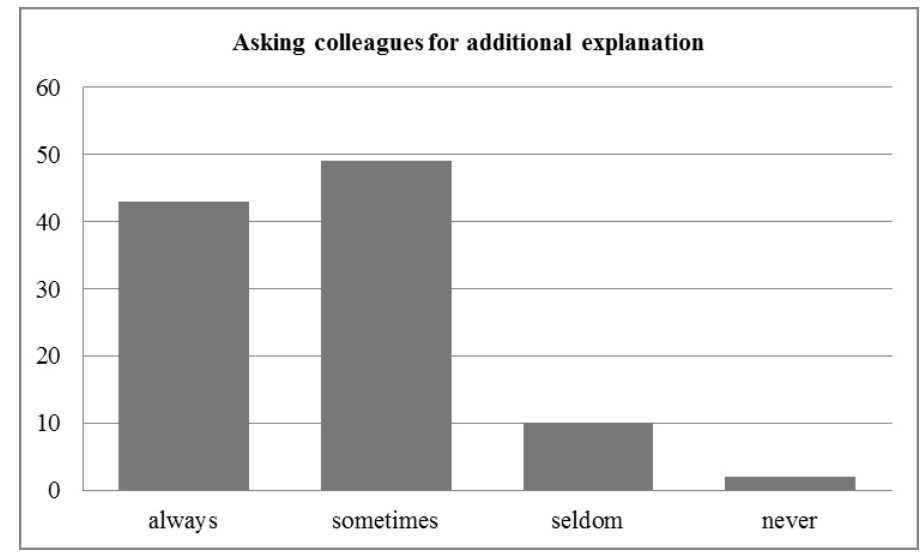

FIGURE 11. ASKING COLLEAGUES FOR ADDITIONAL EXPLANATION 
Regarding the role of the teacher in the learning process, about $81 \%$ of respondents think that the role of the teacher is important, and $16 \%$ think it is fairly important, whereas only $3 \%$ think it is not significant. None of the students thinks that the role of a teacher is not important. We think that the respondents, first-year students, are not quite independent, and they need help from a teacher so as to feel 'safer' and 'comfortable' in the language learning environment.

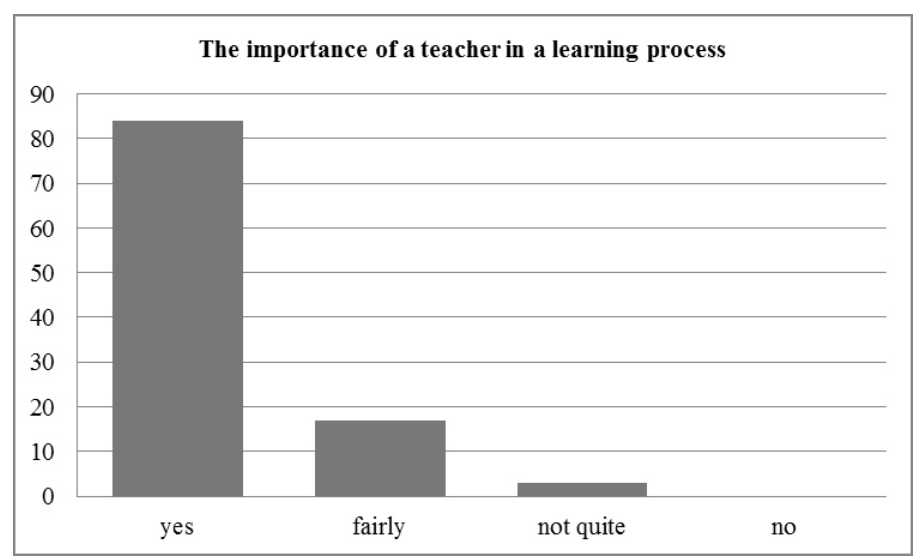

FIGURE 12. THE IMPORTANCE OF A TEACHER IN LEARNING PROCESS

As for using information technology in an ESP context, $62 \%$ liked it, whereas only $5 \%$ did not like it. It appears that most respondents like it, which is quite expected taking into account the accessibility of various information technologies.

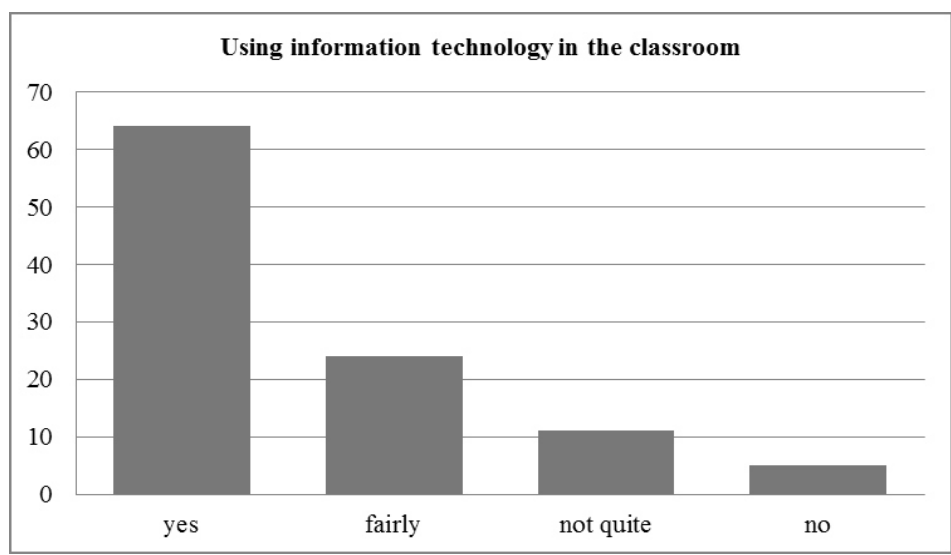

FIGURE 13. USING INFORMATION TECHNOLOGY IN THE CLASSROOM 
When it comes to visiting the Moodle, about $62 \%$ wrote that they visited it frequently, around $26 \%$ of students visited it sometimes, $12 \%$ rarely visited it and $1 \%$ never visited it.

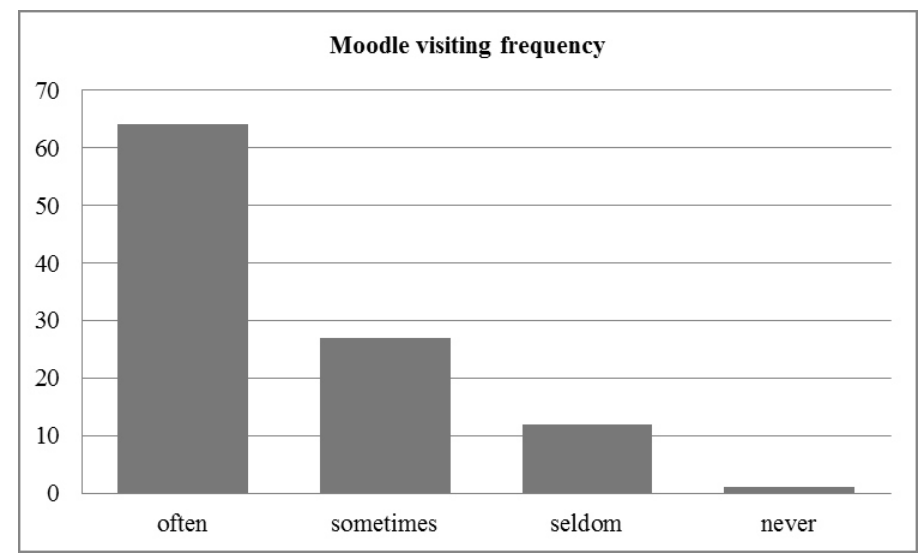

FIGURE 14. MOODLE VISITING FREQUENCY

Asked whether this kind of communication made it easier for them to follow the lectures, about $55 \%$ of the respondents answered positively, $20 \%$ thought that it made it fairly easier, $19 \%$ considered that it did not quite make it easier and $6 \%$ of the respondents answered negatively.

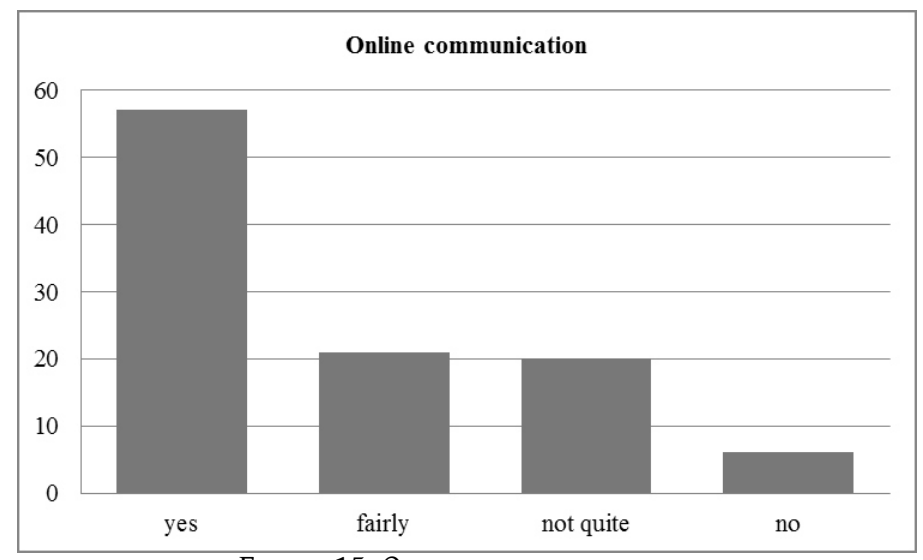

FIGURE 15. ONLINE COMMUNICATION MAKES LEARNING PROCESS EASIER 
Regarding the grades, respondents obtained the following grades on the exam: $10 \%$ achieved a grade of $6,17 \%$ of respondents obtained a grade of $7,11 \%$ got $8,21 \%$ attained 9 and $41 \%$ received 10 . Figure 16 clearly shows that mostly the students who obtained the highest grades were willing to fill out the questionnaire.

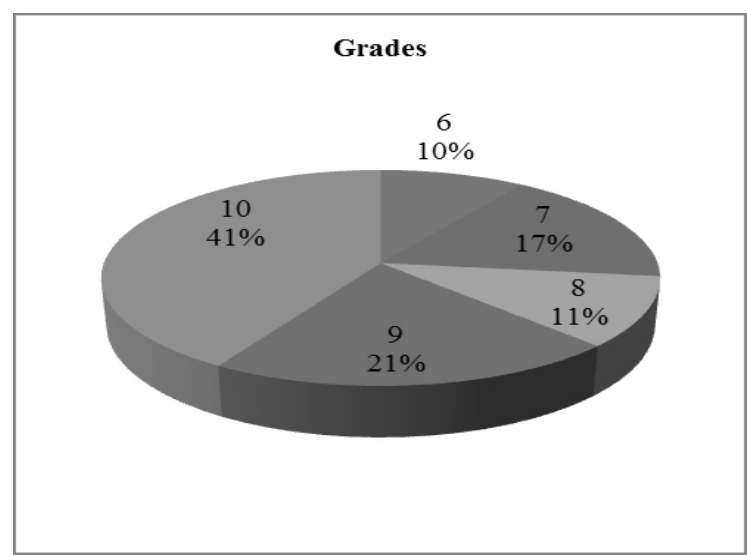

FIGURE 16. GRADES OF THE RESPONDENTS

We also wanted to find out whether there were some correlations between respondents' grades obtained and their self-evaluation, as well as whether there were some correlations between frequency of visiting Moodle and the grades attained, and finally whether there were any correlations between grades and their attitudes towards using information technologies in the classroom.

When we take into account the relation between grades attained and their self-evaluation of English knowledge, we can see from Figure 17 that the range for self-evaluating grades is quite diverse for the grade of seven. The respondents who obtained a grade of 7 evaluated themselves with grades from 1 to 5 , those with self-evaluating grades of 3 and 4 being the most numerous. On the other hand, respondents who obtained a grade of 6 , mostly evaluated their knowledge with grades of 2 and 3, the respondents who obtained 8 mostly evaluated English knowledge with grades 3 and 4, and the respondents who obtained 9 mainly opted for the grade of 4 , whereas the respondents who attained a grade of ten for the most part opted for grades of 4 and 5. 


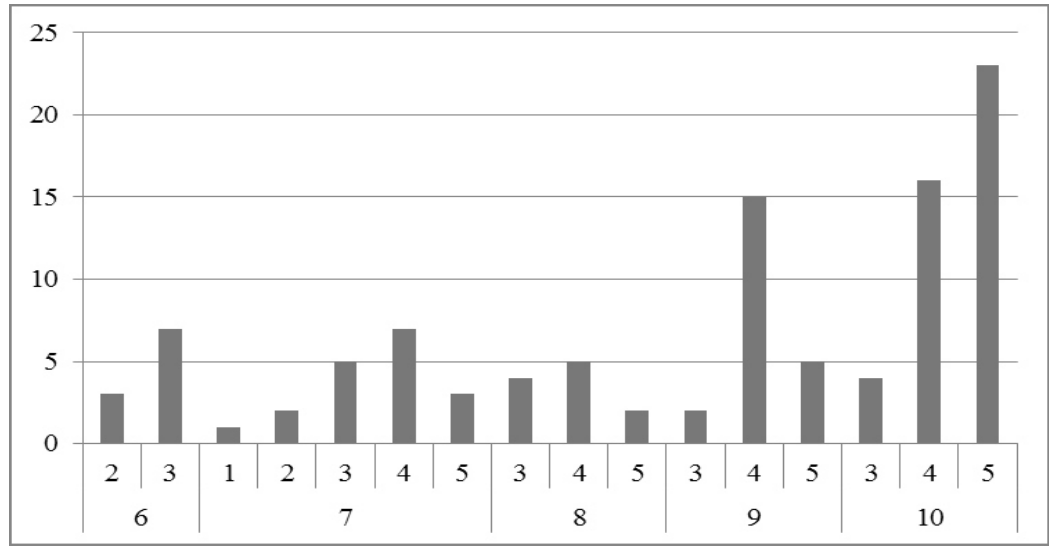

FIGURE 17. CORRELATION BETWEEN GRADES AND SELF-EVALUATION OF THE ENGLISH LANGUAGE

Regarding the correlation between grades and the frequency of visiting Moodle (Figure 18), it can be seen that the respondents who achieved a grade of ten were the most frequent visitors, although there were some respondents in this group who never visited the platform. So it would be wrong to conclude that the frequency of visiting Moodle must have had some significant impacts on the final grade, but it is possible to say that the students who obtained grades 9 and 10 were the most numerous, with an exception of the respondents who obtained 7, whose 'oftenness' was the same as the one of those who obtained 9.

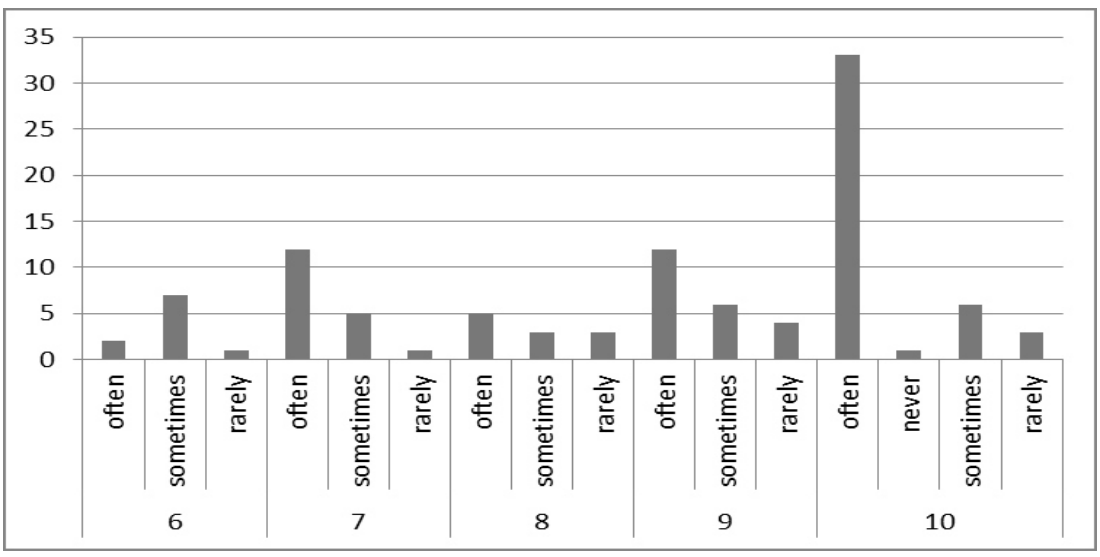

FIGURE 18. CORRELATION BETWEEN GRADES AND FREQUENCY OF VISITING MOODLE 
When it comes to the correlation between grades and whether this kind of communication makes following the lectures easier (Figure 19), we see positive attitudes in case of students who obtained 7, 9 and 10. The positive attitude is also present in the answers of those who achieved 6 and 8 , but to a lesser degree.

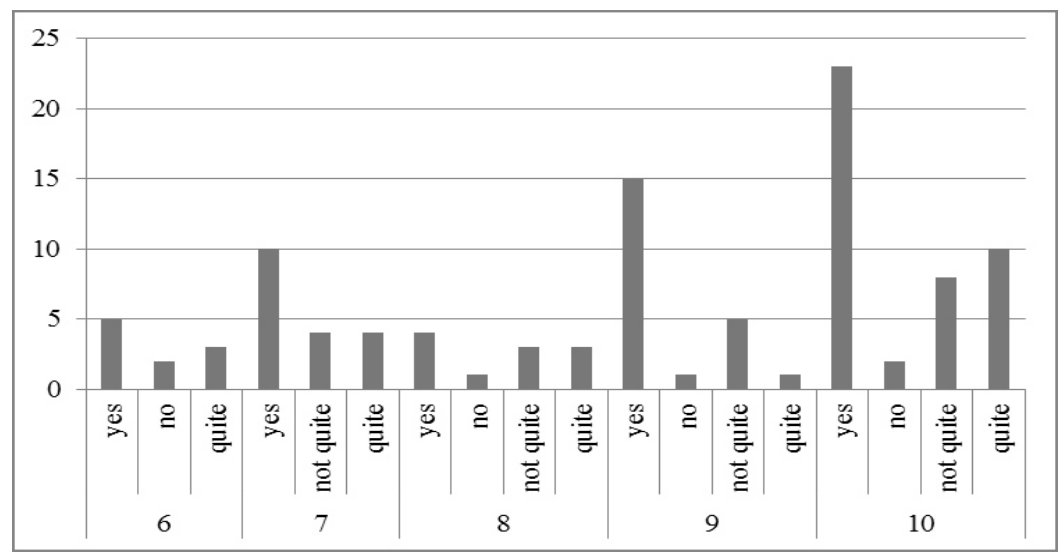

FIGURE 19. CORRELATION BETWEEN GRADES AND ATTITUDES TOWARDS USEFULNESS OF ONLINE COMMUNICATION

If we look at correlation and covariance tables (Figure 20) as well as at scatterplots (Figures 21 and 22), we can see that the correlation coefficient of a relationship between grades and their self-evaluation is 0.590 which can be interpreted as a moderate positive relationship. On the other hand, the correlation coefficient of a relationship between grades and respondents' knowledge of computers is 0.128 (Figure 22), which may mean that it is a weak positive relationship. Thus, it may be possible to assume that there is a dependency between grades and knowledge of English.

\begin{tabular}{|c|c|c|c|}
\hline CORRELATION TABLE & $\begin{array}{c}\text { PLEASE, EVALUATE YOUR } \\
\text { KNOWLEDGE OF ENGLISH } \\
\text { BEFORE ENROLLING ON THE } \\
\text { FACULTY (1-5) }\end{array}$ & $\begin{array}{c}\text { PLEASE, EVALUATE YOUR } \\
\text { KNOWLEDGE OF COMPUTERS } \\
\text { BEFORE ENROLLING ON THE } \\
\text { FACULTY (1-5) }\end{array}$ & $\begin{array}{c}\text { WHICH GRADE DID YOU } \\
\text { OBTAIN? }\end{array}$ \\
\hline $\begin{array}{c}\text { PLEASE, EVALUATE YOUR } \\
\text { KNOWLEDGE OF ENGLISH } \\
\text { BEFORE ENROLLING ON THE } \\
\text { FACULTY (1-5) }\end{array}$ & 1.000 & 0.410 & 0.590 \\
\hline
\end{tabular}

FIGURE 20. CORRELATION AND COVARIANCE TABLES 


\begin{tabular}{|c|c|c|c|}
\hline $\begin{array}{c}\text { PLEASE, EVALUATE YOUR } \\
\text { KNOWLEDGE OF COMPUTERS } \\
\text { BEFORE ENROLLING ON THE } \\
\text { FACULTY }(1-5)\end{array}$ & 0.410 & 1.000 & 0.128 \\
\hline $\begin{array}{c}\text { WHICH GRADE DID YOU } \\
\text { OBTAIN? }\end{array}$ & 0.590 & 0.128 & 1.000 \\
\hline & $\begin{array}{c}\text { PLEASE, EVALUATE YOUR } \\
\text { KNOWLEDGE OF ENGLISH } \\
\text { BEFORE ENROLLING ON THE } \\
\text { FACULTY (1-5) }\end{array}$ & $\begin{array}{c}\text { PLEASE, EVALUATE YOUR } \\
\text { KNOWLEDGE OF COMPUTERS } \\
\text { BEFORE ENROLLING ON THE } \\
\text { FACULTY }(1-5)\end{array}$ & $\begin{array}{c}\text { WHICH GRADE DID YOU } \\
\text { OBTAIN? }\end{array}$ \\
\hline \multicolumn{4}{|l|}{ COVARIANCE TABLE } \\
\hline $\begin{array}{c}\text { PLEASE, EVALUATE YOUR } \\
\text { KNOWLEDGE OF ENGLISH } \\
\text { BEFORE ENROLLING ON THE } \\
\text { FACULTY (1-5) }\end{array}$ & 0.8152 & 0.3075 & 0.7509 \\
\hline $\begin{array}{c}\text { PLEASE, EVALUATE YOUR } \\
\text { KNOWLEDGE OF COMPUTERS } \\
\text { BEFORE ENROLLING ON THE } \\
\text { FACULTY (1-5) }\end{array}$ & 0.3075 & 0.6915 & 0.1499 \\
\hline $\begin{array}{c}\text { WHICH GRADE DID YOU } \\
\text { OBTAIN? }\end{array}$ & 0.7509 & 0.1499 & 1.9892 \\
\hline
\end{tabular}

FIGURE 20. CORRELATION AND COVARIANCE TABLES

Scatterplot of Which grade did you obtain? vs Please, evaluate your knowledge of English before enrolling on the Faculty.

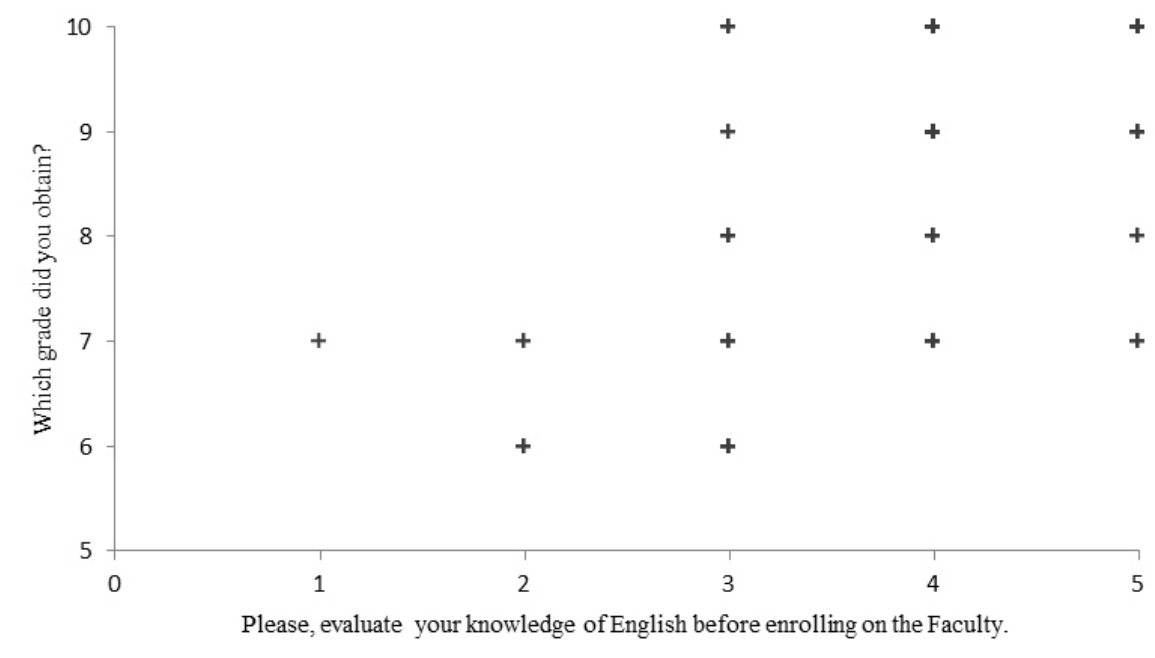

FIGURE 21. SCATTERPLOT OF GRADES OBTAINED VS SELF-EVALUATION OF ENGLISH KNOWLEDGE 


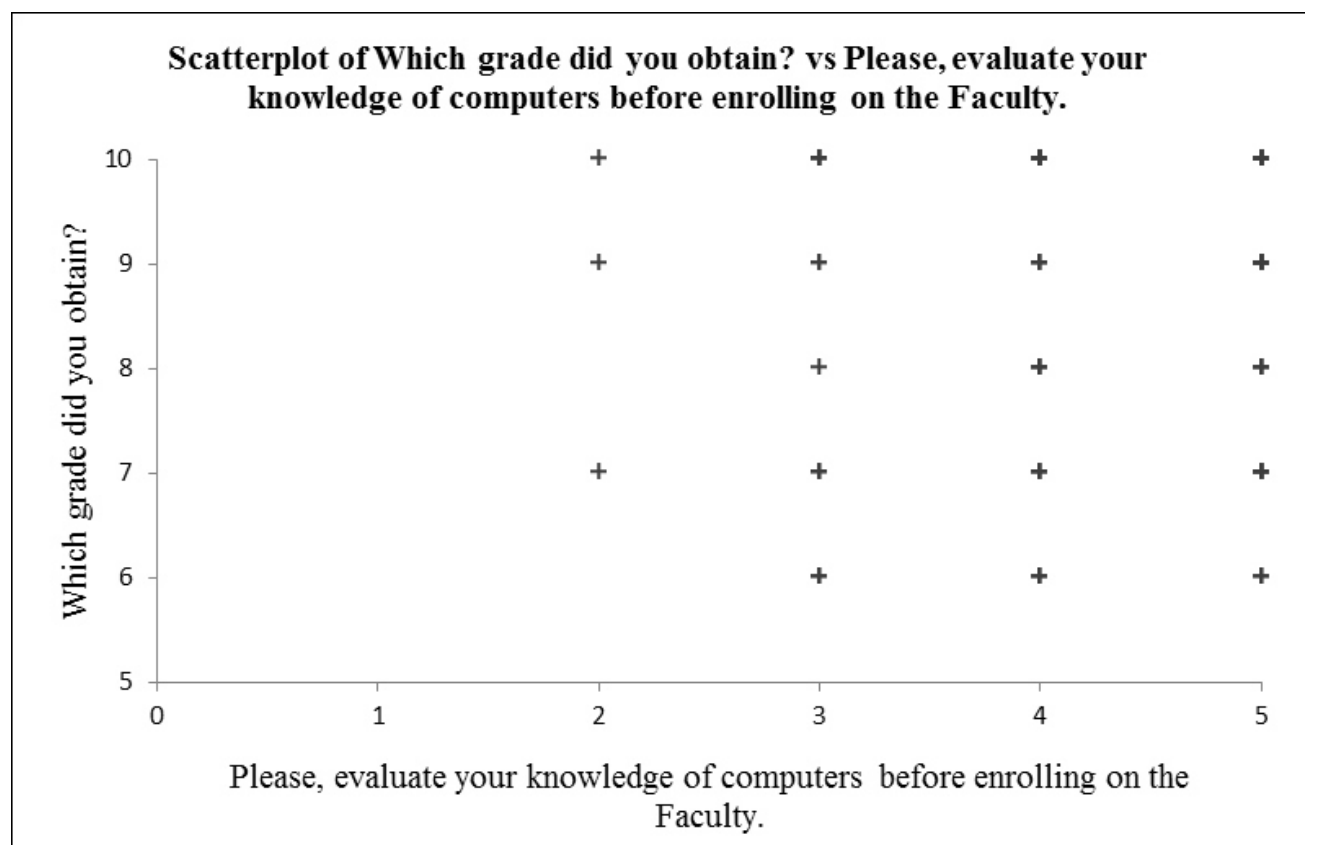

FIGURE 22. SCATTERPLOT OF GRADES OBTAINED VS SELF-EVALUATION OF COMPUTER KNOWLEDGE

CONCLUSIONS Although the questionnaire was mostly filled out by the students who obtained high grades, which may be considered a drawback of this research, considering the students' responses it can be argued that using information technology in the classroom has become a necessity: more than half of the students preferred using it in the classroom. At the same time, it is easily visible from the answers that the best option is blended learning. Most respondents pointed at the possibility to choose time and place that suited them as an advantage, on the other hand, the impossibility to have enough face to face contact with a teacher and other colleagues as well as lack of self-discipline were listed as main disadvantages. Therefore face-to-face classes seem necessary to motivate the students in a more direct way as well as to structure their learning. It is interesting to observe that a small number of respondents opted only for e-learning, which can be interpreted that they are not ready for an independent way of learning. Similarly, they are not willing to do some activities by themselves, for example, reading material, stud- 
ying tables and figures, so it seems that they are not quite familiar with learning on their own.

On the positive side, most of the respondents claimed that they felt some of improvement of their English language knowledge, which could trigger higher motivation for studying English. We can also argue that the frequency of using Moodle to some extent affected the final grades of the respondents in a positive way.

The research also shows that they liked to communicate via the Internet, however, they preferred communicating with their colleagues to communicating with a teacher. Such behaviour may have resulted from shyness or anxiety even though communication with the teacher was not face-to-face. However, a large number of respondents were aware of the importance of the teacher in a learning process. Also, there were positive correlation coefficients of relationships between grades and self-evaluation of respondents' knowledge of English before enrolling on the Faculty as well as between grades and self-evaluation of knowledge of computers before enrolling on the Faculty.

We can easily observe that incorporating Moodle into the "classical' classroom encourages interaction and boost students' confidence regarding their knowledge of English as well as their independence. In addition, it is likely that they will develop learner autonomy, which may help them learn faster and in more diverse ways. In the end, what is interesting to note was that most respondents found using Moodle to be a valuable experience.

Campbell, C., \& Kryszewska, H. (1992). Learner-Based Teaching. Oxford: Oxford University Press.

Deller S. (1990). Lessons from the Learner: Student-Generated Activities for the Language Classroom. Longman Group United Kingdom.

Dougiamas, M. (1998). A journey into Constructivism. Retrieved from http:// dougiamas.com/writing/constructivism.html (accessed 14th April 2014).

Dudeney, G., \& Hockly, N. (2013). Reversing the blend: From online to blended. In Tomlinson, B. \& Whittaker, C. (eds.). Blended Learning in English Language Teaching: Course Design and Implementation https://www.teachingenglish.org. uk/sites/teacheng/files/D057_Blended\%20learning_FINAL_WEB\%200NLY_ v2.pdf 14 (accessed 14th April 2014).

Elias, T. (2010) Universal instructional design principles for Moodle. in The International Review of Research in Open and Distance Learning, Vol 11, No 2 http://files.eric.ed.gov/fulltext/EJ895752.pdf(accessed 14th April 2014). 
Little, D. (1996). Freedom to learn and compulsion to interact: promoting learner autonomy through the use of information systems and information technologies. In: H. D. R. Pemberton, E.S. L. Li, W. W. F. Or, \& H. D. Pierson (Eds.), Taking control: Autonomy in language learning (pp. 203-219). Hong Kong: Hong Kong University Press.

Marsh, D. (2012). Blended Learning: Creating Learning Opportunities for Language Learners. Cambridge: Cambridge University Press.

Shetzer, H., \& Warschauer, M. (2000). An electronic literacy approach to network-based language teaching. In M. Warschauer \& R. Kern (Eds.), Network-based Language Teaching: Concepts and Practice. (pp. 171-185). New York: Cambridge University Press.

Schunk, Dale H. (2012). Learning Theories. An Educational Perspective. Boston: Pearson.

Siek-Piskozub, T. (2006). Constructivism in language pedagogy. In: E. Lorek-Jezińska, T. Siek-Piskozub \& K. Więckowska (Eds.) Words in the making. Constructivism and postmodern knowledge. Torun: Wydawnictwo Uniwersytetu Mikołaja Kopernika, 159-172.

Stefanowicz-Kocoł, A. (2011). Accommodating ESP Students' Needs in a Moodle Based Course Component. In LANGUAGE FOR SPECIFIC PURPOSES:Challenges and Prospects. Belgrade: Foreign Language and Literature Association of Serbia.

Stefanowicz-Kocoł, A. (2015). Motivating ESP learners in a hybrid course. In Z. Perić \& N. Stojković (Eds.), in Proceedings of the 1st International Conference on Teaching English for Specific Purposes. Niš: University of Nis: Faculty of Electronic Engineering, Serbia.

Stefanowicz-Kocoł, A. \& Nowak, S. (2009). Testy, które uczą - ewaluacja sposobu testowania. In B. Niemiecko \& M. K. Szmigiel (Eds.), Badania międzynarodowe $i$ wzory zagraniczne $w$ diagnostyce edukacyjnej. Kielce: PTDE.

Warschauer, M. (2000). The changing global economy and the future of English teaching. TESOL Quarterly, 34, 511-535. 
ДАНИЈЕЛА Д. БОРЂЕВИЋ

УНИВЕРЗИТЕТ У БЕОГРАДУ

ПОљОПРИВРЕДНИ ФАКУЛТЕТ

АНА АПОЛОНИА СТЕФАНОВИЧ-КОЦОЛ

ДРЖАВНА ВИСОКА СТРУЧНА ШКОЛА У ТАРНОВУ

ФАКУЛТЕТ ЗА ХУМАНИСТИЧКЕ НАУКЕ

РЕЗИМЕ

ПЕРЦЕПЦИЈА СТУДЕНАТА О УКљУЧИВАҢУ ПЛАТФOPME MOODLE У КОНТЕКСТ ЕНГЛЕСКОГ ЈЕЗИКА ЗА ПОСЕБНЕ НАМЕНЕ

Примена информационих технологија у настави различитих предмета, па тако и страног језика, на било ком нивоу школовања, постала је готово неизбежна. Платформа MOODLE (енгл. Modular Object-Oriented Dynamic Learning Environment) може се прилично успешно интегрисати ради увођења учења на даљину, као и хибридног учења. У раду су дате теоријске основе о употреби платформе MOODLE у контексту учења на даљину, као и хибридног учења, уз напомене о одређеним могућим потешкоћама и недостацима. Овај рад је имао за циљ да испита да ли су студенти задовољни употребом платформе MOODLE која је коришћена у настави предмета Енілески језик за йосебне намене. Испитаници су ठили студенти Пољопривредног факултета, Универзитета у Београду. Главни циљ овог истраживања био је да се утврди да ли студенти учење на даљину, нарочито платформу MOODLE сматрају корисном за њихово учење. Поред тога, студенти су имали прилике да сами оцене своје познавање рада на рачунару и енглеског језика. Даље, желели смо да сазнамо више о њиховој перцепцији и о ставовима према комуникацији са другим студентима и са наставником, као и о њиховим омиљеним облицима и начинима учења. Затим, сазнали смо које су предности и недостаци употребе информационих технологија у настави страног језика. На основу добијених резултата, може се закључити да је употреба платформе MOODLE у оквиру класичног учења у учионици охрабрила сарадњу и повећала самопоуздање студената у погледу њиховог знања енглеског језика и њихове независности. У вези са тиме, резултати овог истраживања показују да су испитаници били ради да сарађују са својим колегама, да се обрате за помоћ или додатна објашњења. Стога је вероватно да у контексту хибридног учења, студенти могу усвојити неке нове вештине, које би им помогле да уче брже и на различите начине. На крају, желели смо да 
утврдимо како њихова самоевалуација корелира са њиховим ставовима према учењу на даљину како бисмо дошли до закључака који ठи се могли користити као полазна основа за нека будућа истраживања.

КључнЕ РЕчи: Moodle, учење на даљину, енглески језик за посебне намене, перцепција студената.

Овај чланак је објављен и дистрибуира се под лиценцом Creative Commons Ауторство-Некомерцијално-Без прерада 3.0 (CC BY-NC-ND | 3.0 https://creativecommons.org/licenses/by-nc-nd/3.0/). This paper is published and distributed under the terms and conditions of the Creative Commons Attribution-NonCommercial-NoDerivs 3.0 Unported licence (CC BY-NC-ND 3.0 | https://creativecommons.org/licenses/by-nc-nd/3.0/). 